\title{
Polymorphism of Transcription Factor 7-Like 2 in Obese Patients with Type 2 Diabetes Mellitus
}

\author{
Defeng Kong1, Xue Han1, Hang Guo², Rui Xia ${ }^{3 *}$ \\ ${ }^{1}$ Yangtze University, Jingzhou, China \\ ${ }^{2}$ Hospital 984 of PLA, Beijing, China \\ ${ }^{3}$ The First Affiliated Hospital of Yangtze University, Jingzhou, China \\ Email: kdfenter@163.com,00521@163.com, ^879560350@qq.com
}

How to cite this paper: Kong, D.F., Han, X., Guo, H. and Xia, R. (2020) Polymorphism of Transcription Factor 7-Like 2 in Obese Patients with Type 2 Diabetes Mellitus. Journal of Biosciences and Medicines, 8, 9-15.

https://doi.org/10.4236/jbm.2020.811002

Received: September 25, 2020

Accepted: November 3, 2020

Published: November 6, 2020

Copyright $\odot 2020$ by author(s) and Scientific Research Publishing Inc. This work is licensed under the Creative Commons Attribution International License (CC BY 4.0).

http://creativecommons.org/licenses/by/4.0/

\section{Open Access}

\begin{abstract}
Objective: The article is to investigate the relationship between the polymorphism of transcription factor 7-like 2 (TCF7L2) gene rs7903146 and type 2 diabetes mellitus with obesity in Chinese Han population. Methods: 216 patients with type 2 diabetes mellitus (T2DM), 92 males, 124 females, 194 normal controls, 89 males and 105 females. The polymorphism of TCF7L2 gene rs7903146 was measured by PCR-RFLP. PCR amplifier was used for amplification reaction, followed by polymorphism analysis of TCF7L2 gene: the reaction system was $20 \mu \mathrm{l}$, among which restriction endonuclease was 0.5 $\mu \mathrm{l}$ and PCR product was $7.5 \mu \mathrm{l}$. Restriction enzyme SspI (Fermentas) was used for PCR product and was bathed at $37^{\circ} \mathrm{C}$ for $16 \mathrm{~h}$. The enzyme digestion products were detected and genotypes were identified by $2 \%$ agarose gel electrophoresis. The genotyping was repeated in $10 \%$ of the samples, and the genotyping rate was $100 \%$. Height and weight were measured and BMI calculated. According to BMI, the experimental group was further divided into the obese group $\left(\mathrm{n}=137, \mathrm{BMI}>25 \mathrm{~kg} / \mathrm{m}^{2}\right)$ and the normal body mass group $(\mathrm{n}=$ 79 , BMI $<25 \mathrm{kgm}^{2}$ ). Normal control group: BMI $<25 \mathrm{kgm}^{2}:$ FBG $<6.1$ $\mathrm{mmol} / \mathrm{L}$ and $2 \mathrm{~h} \mathrm{BG}<7.8 \mathrm{mmol} / \mathrm{L}$ after meal. Finally, SPSS18.0 software was used for analysis. Results: FBG, 2 h BG, FIN and Lg homa-ir showed significant differences between the control group and the T2DM groups $(P<0.01)$, while no statistical difference was found between the other parameters $(P>$ $0.05)$. There was a significant difference in genotype frequency between the control group and the experimental group $\left(\chi^{2}=17.382, P<0.001\right)$, but no significant difference in allele frequency between the control group and the T2DM group $(P>0.05)$. Genotype frequency at BMI level was significantly different between the control group and the T2DM group $\left(\chi^{2}=20.427, P=\right.$ 0.001 ), but there was no significant difference in allele frequency distribution $(P>0.05)$. The TT type and TC + CC type were significantly different be-
\end{abstract}


tween the T2DM group and the control group $\left(\chi^{2}=78.154, P=0.006\right)$ and the T2DM obesity group and the control group $\left(\chi^{2}=7.247, P=0.009\right)$, but there was no significant difference between the T2DM normal body mass group and the control group $(P>0.05)$. In addition, there was no significant difference between TC type + TT type and CC type between the T2DM group and the control group and the T2DM obesity group and the control group $(P>$ 0.05). Conclusion: There were significant differences in the genotype frequency and recessive inheritance pattern (TT/CC + TC) of rs7903146, suggesting that this SNP may be associated with the incidence of T2DM in obesity and insulin resistance.

\section{Keywords}

Type 2 Diabetes Mellitus, Obese, TCF7L2, Polymorphism Study

\section{Introduction}

China is the second largest number of diabetics in the world with nearly 30 million now [1]. Previous study shows rs7903146 of transcription factor 7-like 2 (TCF7L2) is closely related to the occurrence of type 2 diabetes mellitus (T2DM) in different populations and nationalities, which plays a very important role [2]. Other studies have shown that this gene was associated with increasing body mass index (BMI), increasing LDL cholesterol (LDLC), decreasing triglycerides (RG), decreasing insulin secretion and obesity [3]. In this study, PCR-RFLP was used to investigate the relationship between rs7903146 polymorphism and type 2 diabetes with obesity in Chinese Han population [4].

\section{Research Objects and Methods}

\subsection{Research Objects}

There were 216 cases of Type 2 diabetes in Han nationality, including 92 males and 124 females. There was no blood relationship among the patients and the diagnostic criteria of diabetes were in accordance with the standards stipulated by WHO in 1999. There were 194 healthy subjects in the normal control group, including 89 males and 105 females. There were Han ethnic groups with no history of diabetes, which were impaired glucose tolerance or family history of diabetes and excluded diabetes and impaired glucose tolerance.

\subsection{Polymorphism Determination rs7903146 of TCF7L2 Gene: PCR-RFLP}

Each restriction enzyme genotype was determined by sequencing. 1) PCR primers are shown in Table 1. 2) PCR reaction system $25 \mathrm{~L}$ including $10 \times \mathrm{PCR}$ buffer $2.5 \mathrm{~L} ; \mathrm{Mgcl}_{2}(25$ tendency/L) $2.0 \mathrm{muL}$; DNTP mixture $(2.5 \mathrm{mmol} / \mathrm{L}$ each) $2.0 \mathrm{ul}$; The upper and lower primers were $0.5 \mathrm{~L}$ each. $(20 \mathrm{mu} \mathrm{mol} / \mathrm{L})$; DNA template $1 \mathrm{mul}$; Taq enzyme (5 U/L, Takara, Japan) 0.2 ul double distilled water 16.3 
L. 3) PCR cycle parameters: RS7903146: pre-denaturation at $94^{\circ} \mathrm{C}$ for 5 min: denaturation at $94^{\circ} \mathrm{C}$ for $30 \mathrm{~s}$, annealing at $52.5^{\circ} \mathrm{C}$ for $30 \mathrm{~s}$. It was extended at $72^{\circ} \mathrm{C}$ for $25 \mathrm{~s}$, and after 32 cycles, it was extended at the end at $72^{\circ} \mathrm{C}$ for $5 \mathrm{~min}$. PCR amplification was performed with a PCR amplification instrument (German company Eppendorf), and PCR amplification products were detected by $1 \%$ agarose gel electrophoresis. 4) Polygenicity analysis of TCF7L2 gene: the reaction system was set as $20 \mathrm{~L}$, and the restriction enzyme was $0.5 \mathrm{~L}$ and PCR product was 7.5 L. PCR products were incubated with restriction enzyme SspI (Fermentas) for $16 \mathrm{~h}$ at $37^{\circ} \mathrm{C}$. Enzyme digestion products were detected and genotypes were identified by $2 \%$ agarose gel electrophoresis. PCR products and enzyme digestion products after gel electrophoresis were analyzed by gel imager from Amersham Biosciences, USA. In addition, genotyping was repeated in 10\% of the samples, with a $100 \%$ incidence. They then measured height, weight and calculated BMI.

\subsection{Grouping in T2DM Group}

There were 216 patients including 92 males and 124 females with an average age of $(62.83 \pm 11.45)$ years old. According to body mass index (BMI), they were divided into obese group $\left(\mathrm{n}=137, \mathrm{BMI}>25 \mathrm{~kg} / \mathrm{m}^{2}\right)$ and normal body mass group $\left(\mathrm{n}=79, \mathrm{BM}<25 \mathrm{~kg} / \mathrm{m}^{2}\right) .2$ ) Normal control group: 194 patients, including 89 males and 105 females: mean age $(58.42 \pm 11.93)$ years old: $\mathrm{BMI}<25 \mathrm{~kg} / \mathrm{m}^{2}$; $\mathrm{FBG}<6.1 \mathrm{mmol} / \mathrm{L}$ and $2 \mathrm{~h}$ postpranational $\mathrm{BG}<7.8 \mathrm{mmol} / \mathrm{L}$.

\subsection{Statistical Methods}

SPSS18.0 Software Package was used for Statistical Analysis. The frequency of alleles and genes in each group was in accordance with Hardy-Weinberg equilibrium. The measurement data were expressed as $\mathrm{M} \pm \mathrm{SD}$, and t-test was performed. Comparison of gene and allele frequency distribution was performed by $\chi^{2}$ test. Logistic regression was used to analyze the correlation between genes and alleles and obesity in T2DM patients and $P<0.05$ was considered statistically significant.

\section{Conclusions}

\subsection{The Clinical Data of FBG}

The clinical data of FBG, $2 \mathrm{~h}$ postpranational BG, FIN and LgHOMA-IR were significantly different between the control group and the T2DM groups $(P<$ $0.01)$, while the other parameters showed no statistical difference $(P>0.05)$.

\subsection{TCF7L2 Allele rs7903146 and Its Genotype Frequency Distribution}

Allele frequency and genotype frequency accord with Hardy-Weinberg equilibrium. The results showed that there was a significant difference in genotype frequency between the experimental group and the control group $\left(\chi^{2}=17.382, P\right.$ 
$<0.001$ ), while there was no significant difference in allele frequency distribution between the control group and the T2DM group $(P>0.05)$. The genotype frequency of T2DM patients was significantly different between the control group and the obesity group $\left(\chi^{2}=20.427, P=0.001\right)$. However, there was a significant difference in allele frequency distribution between the two groups $(P>$ 0.05) (Table 2).

\subsection{Group Comparison of TT Type and TC + CC Type}

There was significant difference between T2DM normal body quality group and control group $\left(\chi^{2}=78.154, P=0.006\right)$ and T2DM obesity group and control group $\left(\chi^{2}=7.247, P=0.009\right)$, but there was no significant difference between T2DM normal body quality group and control group $(P>0.05)$. In addition, the group comparison of TT type and TC + CC type showed that there was no significant difference between T2DM and the control group and T2DM obesity group and control group $(P>0.05$, Table 2$)$, but allele $\mathrm{T}$ was associated with

Table 1. Comparison of clinical data between study groups $(M \pm S D)$.

\begin{tabular}{|c|c|c|c|}
\hline \multirow{2}{*}{ Parameter } & \multicolumn{2}{|c|}{ T2DM } & \multirow{2}{*}{$\begin{array}{l}\text { Control group } \\
\quad(n=194)\end{array}$} \\
\hline & $\mathrm{BMI}<25 \mathrm{~kg} / \mathrm{m}^{2}(\mathrm{n}=137)$ & $\mathrm{BMI}>25 \mathrm{~kg} / \mathrm{m}^{2}(\mathrm{n}=79)$ & \\
\hline year & $64.38 \pm 10.92$ & $61.32 \pm 12.16$ & $58.42 \pm 11.93$ \\
\hline $\mathrm{BMI}\left(\mathrm{kg} / \mathrm{m}^{2}\right)$ & $19.82 \pm 2.14$ & $28.72 \pm 2.62$ & $22.32 \pm 2.93$ \\
\hline SBP (mmHg) & $134.42 \pm 21.62$ & $143.72 \pm 22.83$ & $129.76 \pm 19.65$ \\
\hline DBP (mmHg) & $80.42 \pm 4.12$ & $89.85 \pm 9.26$ & $82.64 \pm 7.53$ \\
\hline $\mathrm{TG}(\mathrm{mmol} / \mathrm{L})$ & $1.71 \pm 0.84$ & $2.32 \pm 1.05$ & $1.57 \pm 0.46$ \\
\hline $\mathrm{TC}(\mathrm{mmol} / \mathrm{L})$ & $5.12 \pm 1.38$ & $5.18 \pm 1.29$ & $4.82 \pm 1.04$ \\
\hline $\mathrm{HDL}(\mathrm{mmol} / \mathrm{L})$ & $1.46 \pm 0.45$ & $1.37 \pm 0.25$ & $1.78 \pm 0.51$ \\
\hline $\mathrm{LDL}(\mathrm{mmol} / \mathrm{L})$ & $2.89 \pm 1.12$ & $3.15 \pm 1.42$ & $2.59 \pm 1.08$ \\
\hline $\mathrm{FBG}(\mathrm{mmol} / \mathrm{L})$ & $11.48 \pm 2.16$ & $8.57 \pm 1.42$ & $4.12 \pm 0.82^{\star}$ \\
\hline $2 \mathrm{~h} \mathrm{BG}(\mathrm{mmol} / \mathrm{L})$ & $18.14 \pm 5.96$ & $11.42 \pm 3.76$ & $3.87 \pm 1.34^{*}$ \\
\hline FIN $(\mu \mathrm{IU} / \mathrm{mL})$ & $7.78 \pm 1.62$ & $23.15 \pm 3.94$ & $12.64 \pm 1.73^{\star}$ \\
\hline Lg HOMA-IR & $0.14 \pm 0.02$ & $0.72 \pm 0.14$ & $0.32 \pm 0.08^{\star}$ \\
\hline
\end{tabular}

Note: ${ }^{*}$ refers to $P<0.01$ compared with T2DM group.

Table 2. Frequency distribution of alleles and genotypes between control group and T2DM group (n, \%)

\begin{tabular}{|c|c|c|c|c|c|c|c|c|}
\hline \multirow{2}{*}{ group } & \multirow{2}{*}{$\mathbf{N}$} & \multicolumn{3}{|c|}{ genetype } & \multicolumn{2}{|c|}{ Allele } & \multirow[t]{2}{*}{$\mathrm{CC}+\mathrm{TC}$} & \multirow[t]{2}{*}{ TT } \\
\hline & & CC (\%) & TC (\%) & TT (\%) & $\mathrm{C}$ & $\mathrm{T}$ & & \\
\hline T2DM & 216 & $83(38.4)$ & $105(48.6)$ & $28(13.0)$ & $271(62.7)$ & $161(37.3)$ & $188(87.0)$ & $28(13.0)^{\star}$ \\
\hline $\mathrm{BMI}<25 \mathrm{~kg} / \mathrm{m}^{2}$ & 137 & $51(37.2)$ & $68(49.6)$ & $18(13.2)$ & $170(62.0)$ & $104(38.0)$ & & \\
\hline $\mathrm{BMI}>25 \mathrm{~kg} / \mathrm{m}^{2}$ & 79 & $32(40.5)$ & $37(46.8)$ & $10(12.7)$ & $101(63.9)$ & $57(26.1)$ & & \\
\hline Control group & 194 & $85(43.8)$ & $70(36.1)$ & $39(20.1)$ & $240(61.9)$ & $148(38.1)$ & 155 (79.9) & $39(20.1)$ \\
\hline
\end{tabular}

Note: ${ }^{*}$ refers to $\mathrm{P}<0.01$ compared with the control group. 
T2DM and obesity under recessive inheritance.

\section{Discussion}

In recent years, there has been a global explosion of molecular genetics research aiming at understanding the TCF7L2 polymorphism that predicts the incidence and impact of T2DM in individuals. In this study, the correlation between the onset of type 2 diabetes mellitus and this gene was studied by using case-control method to observe the effect of this gene on genetic factors.

The polymorphism of TCF7L2 gene is closely related to T2DM and several studies have shown that rs7903146 has a higher risk of occurrence. A number of studies have shown the correlation between TCF7L2 genotype and T2DM in caucasians. The most reporting is that T2DM is about $45 \%$ higher in people with a copy of rs7903146 mutation than in normal people. The incidence of T2DM was $141 \%$ higher in people with 2 copies [4]. Other relevant studies showed that this gene was closely correlated with T2DM in European white population and Japanese population. The risk allele increased the OR value by about $30 \%-50 \%$, which was twice as high as other related type 2 diabetes susceptibility genes [5] [6] [7] [8] [9]. Chang YC [10] showed that T alleles of RS1255372 and RS7903146 were rare and low-frequency in Chinese population and they had no obvious correlation with T2DM. A total of 246 subjects were screened for rs7903146 polymorphisms. The C/T2 and C/C genotype frequencies of RS7903146 were 10.4\% and $89.6 \%$, respectively, in the diabetes subgroup (P-T2DM), $6.7 \%$ and $93.3 \%$ in the decreased glucose tolerance group (P-IGT) and $3.3 \%$ and $96.7 \%$ in the normal glucose tolerance subgroup (P-NGT). The genotype frequency difference between the two groups was not statistically significant by $\chi^{2}$ test. The C/T2 and C/C genotypes of RS7903146 had a frequency of $10.4 \%$ and $89.6 \%$ in the PT2DM group, $91.3 \%$ and $8.7 \%$ in the Type 2 diabetes group (ST2DM) and 2.5\% and $97.5 \%$ in the normal control group (NC). $\chi^{2}$ test showed no significant difference in the genotypes of P-T2DM, ST2DM and NC. However, Wang Zhijiang et al. [11] showed that the T allele frequency, CT and TT genotype frequency of RS7903146 were significantly lower in the normal control group than in the T2DM group.

Generally, diabetes is caused by insulin resistance and insufficient insulin secretion [12]. Non-obese patients with T2DM most caused by a lack of insulin secretion and most obese T2DM patients with insulin resistance. This research was further divided into normal body mass group $\left(\mathrm{BMl}<25 \mathrm{~kg} / \mathrm{m}^{2}\right)$ and obese group (BMI $>25 \mathrm{kgm}^{2}$ ) of the group of T2DM. BMI is a clinical index of T2DM population stratification. This study showed that the experimental index based on BMI level was consistent with the clinical classification. TCF7L2 gene polymorphism locus rs7903146 recessive genetic pattern (TT/CC+TC) and its genotype frequency were significantly different suggesting that this gene polymorphism locus may be related to the incidence of T2DM in obesity and insulin resistance. However, the area of introns rs7903146 polymorphism loci located in gene, 
which is directly involved in the regulation of gene function and expression change. There maybe just a real pathogenic polymorphisms of polymorphism loci in linkage disequilibrium logo and need further studies to prove gene function.

\section{Acknowledgements}

This study represents original work. It was completed recently and has not been published elsewhere. All of the authors of this paper contributed to the work, contributed in preparation of the manuscript, and have provided their final approval for the manuscript submission. The authors thank Rui Xia, Professor, Yangtze University for his contribution in preparation of the manuscript.

\section{Conflicts of Interest}

The authors declare no conflicts of interest regarding the publication of this paper.

\section{References}

[1] Chan, J.C.N., Zhang, Y.Y. and Ning, G. (2014) Diabetes in China: A Societal Solution for a Personal Challenge. The Lancet. Diabetes \& Endocrinology, 2, 969-979. https://doi.org/10.1016/S2213-8587(14)70144-5

[2] Hussain, H., et al. (2014) TCF7L2 rs7903146 Polymorphism and Diabetic Nephropathy Association Is Not Independent of Type 2 Diabetes-A Study in a South Indian Population and Meta-Analysis. Endokrynologia Polska, 65, 298-305.

[3] Shokouhi, S., et al. (2014) Association of rs7903146, rs12255372, and rs290487 Polymorphisms in TCF7L2 Gene with Type 2 Diabetes in an Iranian Kurdish Ethnic Group. Clinical Laboratory, 60, 1269-1276. https://doi.org/10.7754/Clin.Lab.2013.130809

[4] Cauchi, S., et al. (2008) Effects of TCF7L2 Polymorphisms on Obesity in European Populations. Obesity (Silver Spring, Md.), 16, 476-482. https://doi.org/10.1038/oby.2007.77

[5] Groves, C.J., et al. (2006) Association Analysis of 6736 U. K. Subjects Provides Replication and Confirms TCF7L2 as a Type 2 Diabetes Susceptibility Gene with a Substantial Effect on Individual Risk. Diabetes, 55, 2640-2644. https://doi.org/10.2337/db06-0355

[6] Sladek, R., et al. (2007) A Genome-Wide Association Study Identifies Novel Risk Loci for Type 2 Diabetes. Nature, 445, 881-885. https://doi.org/10.1038/nature05616

[7] Chandak, G.R., et al. (2007) Common Variants in the TCF7L2 Gene Are Strongly Associated with Type 2 Diabetes Mellitus in the Indian Population. Diabetologia, 50, 63-67. https://doi.org/10.1007/s00125-006-0502-2

[8] Hayashi, T., et al. (2007) Replication Study for the Association of TCF7L2 with Susceptibility to Type 2 Diabetes in a Japanese Population. Diabetologia, 50, 980-984. https://doi.org/10.1007/s00125-007-0618-Z

[9] Zeggini, E. and McCarthy, M.I. (2007) TCF7L2: The Biggest Story in Diabetes Genetics since HLA? Diabetologia, 50, 1-4. https://doi.org/10.1007/s00125-006-0507-x

[10] Chang, Y.C., et al. (2007) Association Study of the Genetic Polymorphisms of the Transcription Factor 7-Like 2 (TCF7L2) Gene and Type 2 Diabetes in the Chinese Population. Diabetes, 56, 2631-7. https://doi.org/10.2337/db07-1302

[11] Wang, Z.H., et al. (2009) Association between TCF7L2 Gene Polymorphism and 
Type 2 Diabetes in Chinese Han Population. Chinese Journal of Endocrine and $\mathrm{Me}$ tabolism, 2, 139-143.

[12] Bodlaj, G., et al. (2006) Prevalence, Severity and Predictors of HOMA-Estimated Insulin Resistance in Diabetic and Nondiabetic Patients with End-Stage Renal Disease. Journal of Nephrology, 19, 607-612. 